\title{
Cooperative Learning Strategy in teaching Arabic for Non Native Speakers
}

\author{
Suo Yan Mei \\ Senior lecturer at sultan Idris education university Malaysia \\ Suo Yan Ju \\ Lecturer at Islamic science university Malaysia
}

Ayishah Binti Mohd

Students at sultan Idris education university Malaysia

\begin{abstract}
Cooperative learning is a teaching strategy that can help students to be successful in academic achievement and skills, as well as can assist the students to enhance the social interaction and human relation; however, this research explored the cooperative learning strategy in teaching Arabic for non native speakers, and will show the experiences for Arabic lecturers during their applying this method for teaching Arabic at sultan Idris education university Malaysia. The researchers will depend on the survey research design. The study will use a sample of 10 lecturers who are teaching Arabic language randomly selected from Sultan Idris education University Malaysia. The method will use data collection which included a 10-items questionnaire. Results show that majority of lecturers strongly support to apply the cooperative learning during the classes and outside of classes to help the students to improve their language skills, communication skills and social interaction .
\end{abstract}

Keywords: Cooperative learning, Strategy, Teaching, Arabic, Non Native Speakers

\section{Introduction}

Teaching Arabic for non Arabic speaker is not successful if the teachers did not use proper strategies and approaches during the teaching. We are living now at 21 century era, the era of technology, the teaching tool and strategy already changed according to developing of era. But still a lot of teachers and lecturers are using traditional teaching method without any changing in the classroom, especially in high learning institute. However, the teacher - centre approach is not suitable for the students in the university any more, the university students unlike the students in the school have ability to search knowledge by themselves, and have creative and critical thinking skill, the lecturer in the university just like facilities to guide them to search the knowledge. Therefore, students- centre approaches are very strong recommending within the teaching in the university, like discover -based learning, problem- based learning, and Cooperative learning approaches.

Cooperative learning is a teaching strategy that can help students to be successful in academic achievement and skills, as well as can assist the students to enhance the social interaction and human relation (Slavin, 2009). It was developed from social psychological studies of cooperation and competition inhuman behavior (Deutsh, 1949). Since the early 1970s, cooperative learning has one of the greatest success stores in the history of educational innovation, cooperative learning strategy is now so common place that they are often seen as standard part of education practice, not as a innovation (Slavin1999).

Here, this research aims to export how effective for application of cooperative learning strategy in teaching Arabic for non native speakers in Sultan Idris Education University Malaysia, as well as to investigate any of relevant skills which effected by using cooperative teaching. The researchers will administer to a sample for 10 lecturers at this University。

\section{Problem Statement}


Teaching language for non native speaker at non native speaker is always discussed by expertise of language and education, especial teaching Arabic language, many of teachers and lectures of Arabic language are very experts in language but not experts in education and teaching, that why, nowadays, many of them still use traditional teaching method without changing and without depends on the technology to teach Arabic language. During the Arabic class, students just listen and take note from lecturer, after the class, they don't practice any skills for the Arabic language, as well as there are very limited research discussed about good strategies for teaching Arabic. Therefore, this research aims to distribute the effects and benefit of students self directed learning in learning Arabic process, which is called cooperative learning in Arabic teaching to fulfill the gap of the research field on this topic.

\section{Hypothesis}

This study will state some of the relevant hypothesis as following:

1. All lecturers are using students centre strategy, especial cooperative learning.

2. All lecturers think that cooperative learning can help them to improve students' language skills, social interaction between students and lectures.

3. Cooperative learning benefit and effect to teaching and learning Arabic language.

\section{Research Questions}

This study wills cover following questions:

1. What kind of strategies using by the lecturers to teaching Arabic language?

2. What is perception of lecturers for cooperative learning?

3. Is cooperative learning benefit and effect to teaching and learning Arabic language?

\section{Research Objectives}

The objectives of this research will investigate:

1. The strategies using by the lecturers to teaching Arabic language in Sultan Idris Education University.

2. The perception of lectures for cooperative learning in teaching and learning Arabic language.

3. The benefit and effect of teaching and learning Arabic language by using cooperative learning strategy.

\section{Importance / benefits of Research}

This topic was discussed as a Zero in the academic education field, according to successful result of teaching foreign or English language by using cooperative learning for certain researchs, this study will benefit to the Arabic lecturer and students who are majoring in Arabic language. As well as, will fulfill the gap of academic research field.

\section{Literature review}

Since cooperative learning became common teaching strategy in the world, there are researches discussed about this topic in different field and promote to apply this strategy in the teaching and learning process. Even thought, the topic about "cooperative learning in teaching Arabic language" is very limited, but still some researchers are relevant to this research.

There is a research titled "Cooperative learning in lectures of an advanced electrical engineering course" by Myllymaki (Myllymaki2012). The researcher discussed about A cooperative learning (group work) method was applied in lectures of an advanced engineering course in Microelectronics Packaging Technology and Reliability at university of oulu in finland, The study provided some valuable insights into the effects of group work, and a student feedback system in an engineering context, and was arranged in a course of twelve lectures, a practical exercise, and five exams, and it was observed by several teacher colleagues. The course provided a solid structure of learning events, which were able to improve the students' learning and give them a positive picture of the technology field. The author found that the group work will not 
automatically bring better results for students who have weaker earlier knowledge in the field. As well as, learning new teaching methods takes time for both the lecturer and the students. Besides that, the finding shows that using the student feedback system after every lecture was perhaps the most positive result of this study.

Kagan cooperative learning model also always discussed by educational scholars, as a topic covered about teaching foreign language by using Kagan cooperative learning approach , titled "Kagan Cooperative Learning Model: The Bridge to Foreign Language Learning in the Third

Millennium" (davoudi, 2012). The reseracher agreed that Kagan coopertive learning model is one of the best model among this strategy to teach and learn foreign langauge, and to improve the socail interaction skill and employability. According to studying of the researcher, Kagan cooperative learning structures enable students to work as teams inside and outside of the classroom . The structures of Kagan cooperative learning enable students to learn language together without feeling alone , but supported each other among the group members .the students learn multiple ways to solve language problem and learn to tackle a language challenge as a group. Students become skillful to express their ideas, attitudes and feelings.

Based on study of this research, we can apply cooperative learning in any foreign language, and Arabic language is not exceptional.

Since some questions asked the reasons for applying cooperative learning in the teaching and learning process is better than teacher centre method, there is a study discussed about101 reasons for using cooperative learning in biology teaching (lord, 2001). Based on the author's review of the study, he summarized certain reasons for using cooperative learning in biology teaching, the cooperative learning will enhance the social skill, practical skill, social thinking, attitudes, instruction, evaluation, value and learning environment. As well as, cooperative learning show to up grant the language skills, model real life and supporting learners without difference ship between gender. According to his review, he tried to study those reasons. He found that when done correctly, cooperative learning is much more offer for biology students than traditional teachers centre method.

If we are language teachers or lectures, during teaching language, we need to teach poetry also. So, what is best strategy to teach poetry? Here, a study suggested to using cooperative learning in teaching poetry. This study emphasized on "effect of cooperative learning in teaching poetry" (Chemwei, Bernard;Kiboss, Joel K;llieva, Emillia 2005). This study was to determine the effects that cooperative learning in school literature has on student's academic achievement, as well as on the learning of poetry in baring district secondary school. The research by poetry achievement test and students interview guide found that students using cooperative learning tend to perform better than their counterparts using conventional or so called regular methods and using cooperative learning has potential to engage learners in active participation in poetry learning process.

According to our review, we found that very limited literature which is talking about cooperative learning in Arabic teaching, and we found there is a PHD dissertation relevant to the topic titled "Effects of cooperative Learning on achievement in Arabic writing and social skills for form two students in Selangor, Malaysia". (ABDUL-HAMED, 2004). This study is a experimental research to explore the problem among students of Arabic as a second language in Malaysian secondary schools in applying Arabic writing rules in their writing tasks. The problem was based on the unique factors of Arabic writing skills and an unsystematic application of general academic writing skills which caused low scores among students in their Arabic as a second language paper. Also, the study determined the relationship between learners' social skills and their achievements in Arabic writing papers. The study compared between the effectiveness of Cooperative Integrated Reading and Composition with Teacher-Centered instruction method.

The researcher found that the significant differences in mean scores on Arabic writing an overall significant correlation $r=$ .71 in determining the relationship between achievement in Arabic writing and students' social skills.

\section{Research methodology}

The researchers will depend on the survey research design. The study will use a sample of 10 lecturers who are teaching Arabic language randomly selected from Sultan Idris education University Malaysia. The method will use for data collection will be a 10-item questionnaire.. The response pattern was in the form of strongly agree, agree, disagree, and strongly disagree, and not sure. These were weighted $5,4,3,2$, and 1 respectively for the data analysis's purpose . Percentages were used to describe this. However, some theoretical framework will also support to this research. 


\section{Finding and discussion}

The following Table 1 which included 5 questions presents the importance of applying cooperative learning method in teaching Arabic language

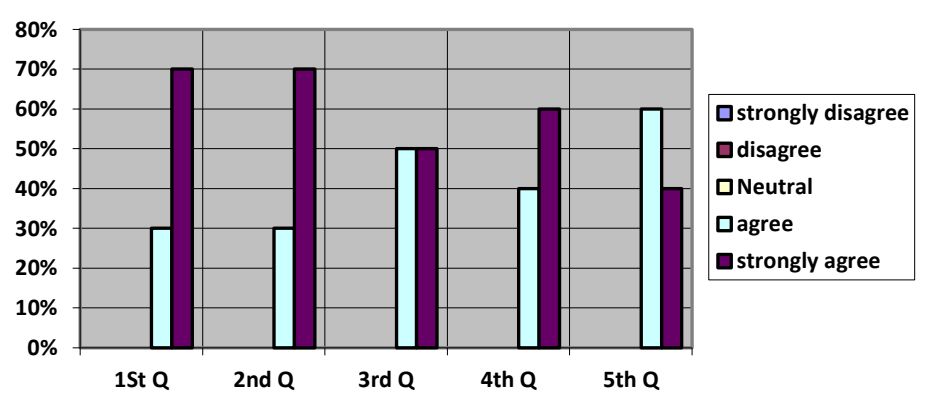

Q1. Appling cooperative learning is important in learning Arabic language.

Q2. Applying cooperative learning is making easy for learning Arabic language.

Q3. Applying cooperative learning can provide new experiences and make learning more thoroughness and focused.

Q4. Applying cooperative learning improve language skills (speaking, listening, reading and writing).

Q5. Applying cooperative learning provide students to get the knowledge.

The table above shows that the percentage of responders, and we can see that majority of participants agreed the 5 questions which mentioned above. The question 1 and 2 shows that $30 \%$ of participants agreed that Appling cooperative learning is important and easy in learning Arabic language, and $70 \%$ of participants strongly agreed that. The result of $Q 3$ shows that $40 \%$ of participants agreed that Applying cooperative learning can provide new experiences and make learning more thoroughness and focused, and $60 \%$ of them strongly agreed that. From the chart, we can see that Question 4 and question 5 also shows that the supporters are majority of participants .

Based on the previous data and the information, the researchers found that a majority of respondents know the method of cooperative learning in terms of their reality. They also know about its importance and role in the process of teaching Arabic language. In summary, most respondents agree that the cooperative learning method is very important And none of the respondents objected to the importance of cooperative learning.

The following table 2 which included 5 questions to show the lecturer ' perceptions of the implementing for cooperative learning.

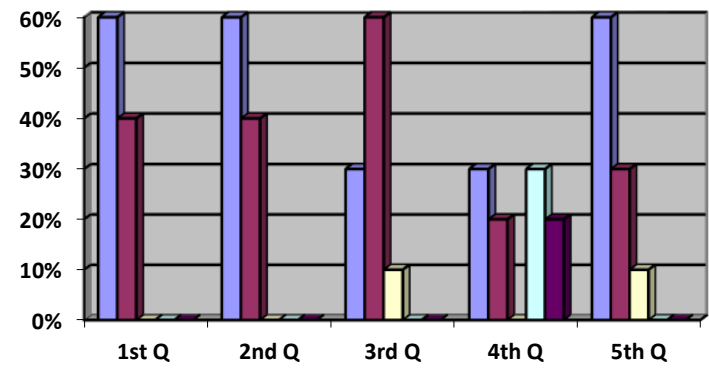

\section{口Strongly Agree \\ $\square$ Agree \\ 口Neutral \\ 口Disagree \\ 口Strongly Disagree}

Q1. Using the cooperative learning method plays an important role in increasing linguistic growth for the students. 
Q2. Cooperative learning Method helps Lecturers to practice activities in the process of teaching Arabic language

Q3. Implement Cooperative learning Method in the process of teaching Arabic language is necessary matter .

Q4. I know the theory of cooperative learning, but don't know how to apply it in teaching Arabic language.

Q5. Cooperative learning helps students to be independent.

The table above shows that the percentage of responders, and it indicated that the question 1 and 2 shows that $40 \%$ of participants agreed that Using the cooperative learning method Plays an important role in increasing linguistic growth for the students and helps Lecturers to practice activities in the process of teaching Arabic language . However, $60 \%$ of participants strongly agreed that. The result of $Q 3$ shows that $30 \%$ of participants agreed that Implement Cooperative learning Method in the process of teaching Arabic language is necessary matter, and $60 \%$ of them strongly agreed that. And $10 \%$ of participants are cannot make sure. From the chart, we can see that Question 4 indicated only half of participants agreed that they know the theory of cooperative learning, but they don't know how to apply it in teaching Arabic language. As well as they are $50 \%$ of them disagreed this question. May they did not know about this theory, and don't know how to apply as well. And question 5 that also shows that Cooperative learning helps students to be independent is supported By majority of participants. Only $10 \%$ of participants are not sure about answer.

Based on the response of the respondents, the researchers found that the perception of the lecturers and their perceptions in the method of cooperative learning is very good. They want to use the different cooperative learning method suitable and attractive to them. The researcher noted that most respondents make sure that the application of cooperative learning method can increase their level and achievement in Arabic The researcher concludes that respondents want to apply cooperative learning within the Arabic language and beyond, and believe that its application is capable of increasing their understanding and helping them to raise their level of Arabic language.

\section{Conclusion}

This research discuss about application of cooperative learning in of Arabic language teaching at the Sultan Idris University. The researchers presented the questionnaire to the Lecturers in the Arabic language department at this university. The questionnaire contains elements in the application of cooperative learning method especially in Arabic language as a model for this research .

The researchers found that many respondents agreed and know the reality of the application of cooperative learning method, and know it's importance, especially in the Arabic language teaching. Through the perceptions of the lecturers on the of cooperative learning application, the researchers found that the lecturers like to apply this method in Arabic class because it helps students to understand class easily and effectively, as well as assist students to Improve their language skills and to enhance the social interaction and human relation.

\section{References}

[1] ABDUL-HAMED, K. R. (2004). Effects of cooperative learning on achievment in arabic writing and social skills for form two students in selangor, malaysia.

[2] Chemwei, Bernard;Kiboss, Joel K;llieva, Emillia(2005). Effect of cooperative learning in teaching poetry. Thinking classroom, International reading association, Vol 6, No 4. Pg, 25-33.

[3] Chen J, Wang Y ( 2013). A Study of Cooperative Learning in Higher College English Teaching

[4] Theory and Practice in Language Studies, Vol. 3, No. 7, July 2013, ACADEMY PUBLISHER Manufactured in Finland. pp. 1258-1263, ISSN 1799-2591

[5] Chen Hsuan-Yu (2011). Structuring Cooperative Learning in Teaching English Pronunciation. English Language Teaching ,Vol. 4, No. 3; September 2011, pg. 26.

[6] davoudi, a. H. (2012). Kagan coopertive learning model: the bridge to foreign langauge learning in the third Millennium. theory and practice in langaue studies , 2 (6), Finland : ACADEMY PUBLISHER, ISSN 1799-2591, pg 1134-1140. 
[7] Deutsh, M. (1949). A theory of cooperation and competition. Human Relation, 2, pg57-71.

[8] Henderson, Tammy L;Martin, Kasey J(2002). Cooperative learning as one approach to teaching family law. Family Relations; Oct 2002; 51, 4; ProQuest Education Journals, pg. 351

[9] Hsiung, Chin-Min (2012). The Effectiveness of Cooperative Learning, Journal of Engineering Education; Jan 2012; 101, 1; ProQuest Education Journals, pg. 119

[10] Myllymaki. (April 2012.). Cooperative laerning in lecttures of an advanced electrical engineering course .International Journal of Electrical Engineering Education, Volume 49, Number 2 ,Manchester University Press . http://dx.doi.org/10.7227//JEEE.49.2.5

[11] Lord, Thomas R. (2001). 101 Reasons for using coopertive learning in biology teaching. The American Biology Teacher. 63 , 1, pg. 30.

[12] Slavin, R. E(2009). educational psychology: theory and practice( $9^{\text {th }}$ ed). New Jersey: pearson Education

[13] Slavin, R. E. (1999, spring ). comperhesive appraochs in coopertive Learning. Pr- Quest, pg74. 